УДК 94(495).01-03+796

https://doi.org/10.24852/2587-6112.2020.6.165.178

\title{
РОЛЬ ФИЗИЧЕСКОЙ КУЛЬТУРЫ И СПОРТА \\ В ПОДГОТОВКЕ МАССОВОГО ПРИЗЫВНОГО КОНТИНГЕНТА В ВИЗАНТИЙСКОЙ ИМПЕРИИ
}

\author{
(C) 2020 г. В. В. Хапаев, А. М. Глушич
}

В статье изучена роль физической культуры и спорта в процессе подготовки византийских воинов в ранневизантийский и средневизантийский периоды. Рассмотрены различные виды спортивных игр и состязаний - как детских и юношеских, благодаря которым обеспечивалась допризывная подготовка, так и военно-спортивные упражнения и соревнования в византийской армии. Сделан вывод о том, что, несмотря на ликвидацию античной системы палестр и гимнасиев, массовая физическая подготовка византийских мальчиков, подростков и юношей призывного возраста в Византии представляла собой хорошо продуманную и логично выстроенную систему, нацеленную на воспитание сильного, смелого и закаленного воина. Ее принципиальное отличие от античного периода заключалось в том, что физическое воспитание детей и подростков было возложено не на государство или общину, а на семью. Задачей общины при этом было создание условий для проведения спортивных соревнований, а государство подключалось к физическому воспитанию юношей после их включения в воинские списки в ходе учений и боевых походов.

Ключевые слова: Византия, физическая культура, спорт, стрельба из лука, борьба, кулачный бой, панкратион, петрополемос, ампра.

\section{THE ROLE OF PHYSICAL CULTURE AND SPORTS IN THE TRAINING OF MASS CONSCRIPTS IN THE BYZANTINE EMPIRE}

\author{
V. V. Khapaev, A. M. Glushich
}

The paper examines the role of physical culture and sports in the process of training Byzantine warriors in the Early and Middle Byzantine periods. Various types of sports games and competitions are considered - both for children and youth, by means of which pre-conscription training was provided, as well as military sports exercises and competitions in the Byzantine army. It is concluded that despite the elimination of the ancient system of palaestra and gymnasia, the mass physical training of Byzantine boys, adolescents and youth of military age in Byzantium was a profound and logical system aimed at the development of strong, courageous and tempered warriors. Its fundamental difference from the ancient period was that the primary physical education of children and adolescents was entrusted not to the state or community, but to the family. The task of the community was to create conditions for holding sports competitions, whereas the state was involved in the physical education of young men after they were included in military lists during maneuvers and military campaigns.

Keywords: Byzantium, physical culture, sports, archery, wrestling, fistfight, pankration, petropolemos, ampra.

Избегающий нести военную службу в качестве стратиота пусть будет наказан сурово, ибо уклонение от военной обязанности есть преступление. Призванные на военную службу и избегающие ее обращаются в рабство как предатели свободы родиныл.

Византийский воинский закон (VIII(?) в.).

Со времен Средневековья западноевропейские авторы тиражировали представление о Византии как о не способной защитить себя стране «изнеженных данайцев» (Титмар, 2009, с. 188). В Новое и Новейшее время эта точка зрения стала доминировать и в среде византинистов, особенно изучающих историю культуры этой страны.
Сформировался стереотип, что ромеи были сосредоточены на духовных практиках и «умерщвлении плоти» (Лазарев, 1986, с. 16). На самом деле в Империи Ромеев, как правило, со всех сторон окруженной врагами, посягавшими на ее территорию и ресурсы, огромное внимание уделялось военному делу, а значит, физической подготовке 
воинов - как рядовых, так и командного состава.

В историографии проблемам изучения военно-прикладной составляющей византийского спорта уделяется недостаточно внимания. Как зарубежные (Guilland, 1965; Crowther, 1996; Giatsis, 2000; Wolińska, 2011), так и отечественные (Успенский, 1894; Дьяконов, 1945; Левченко, 1947; Чекалова, 1982) исследователи сосредоточены главным образом на изучении истории зрелищного соревновательного спорта, в первую очередь, конных ристаний на ипподромах Константинополя и других городов империи, и связанных с этим вопросов о сущности партий ипподрома.

Военно-прикладной аспект физического воспитания ромеев отчасти освещен в трудах греческих исследователей - Ф. Кукулиса (Коvкоvдє́s,, 1948; 1949) и С.Г. Гиациса (Giatsis, 2007), а также в публикации одного из авторов настоящей статьи (Хапаев, 2015). Военно-спортивным практикам поздневизантийского периода уделяется особенно мало внимания, но это - тема для отдельного исследования.

Для осознания причин военных успехов империи - во время Юстиниановой (VI в.) и Македонской (X в.) реконкист, стойкости ее воинов в сопротивлении персидскому, аварскому, арабскому нашествиям VI-VIII вв., для углубленного понимания сущности фемного строя Византии, изучение физической культуры византийцев, и в особенности ее военноприкладного аспекта, необходимо.

Дошедшая до наших дней источниковая база позволяет это сделать. Вопросы физической подготовки рядовых воинов подробно освещены в воинских трактатах VI-X веков. Особую ценность в этом плане представляют следующие наставления: Анонимный трактат VI века «О стратегии» (2007), «Стратегикон» Маврикия (582-602) (Стратегикон, 2004), «Тактика» Льва VI (886-912) (Тактика Льва, 2012), «Стратегика» Никифора Фоки (963969) (Стратегика, 2005). Они содержат сведения о ряде важных для нашего исследования аспектов: что входило в программу физической подготовки в войсках, нормы физических кондиций воинов и полководцев. Особое внимание уделено описанию отработки навыков стрельбы из лука, которыми должен был владеть каждый ромей. Идеал атлета и воина, которому следовали и знатные, и простые ромеи, сформулирован в произведениях художественной литературы, созданных в период успехов византийской реконкисты: «Армурис» IX-XI вв. (Армурис, 1968) и «Дигенис Акрит» X-XII вв. (Дигенис Акрит, 1960).

В византийских исторических сочинениях содержится большой объем информации о физических кондициях и спортивных (точнее военно-спортивных) увлечениях императоров и представителей военной элиты империи. Наиболее информативны в этом плане «Жизнеописания византийских царей» Продолжателя Феофана (Продолжатель Феофана, 1992), «Хронография» Михаила Пселла (Михаил Пселл, 1978) и «История ромеев» Никифора Григоры, в которых уделено большое внимание физической подготовке императоров и их участию в соревнованиях, как скрытых от посторонних глаз, так и публичных (Никифор Григора, 2013). А вот сведения о физической подготовке простолюдинов отрывочны, а потому, трудно поддаются анализу и датировке. Наиболее полное их собрание из разновременных и разнохарактерных источников содержится в шеститомном труде Ф. Кукулиса «Жизнь и культура Византии» (Коvкоvдє́s, 1948; 1949), опубликованном на архаизированном греческом языке (кафаревусе) в Афинах в 1948-1949 гг. С тех пор этот труд не переиздавался и на другие языки не переводился ${ }^{1}$.

Некоторый объем информации можно почерпнуть из изобразительных источников. Отметим в этой связи консульские диптихи V-VI вв., на которых изображены сцены соревнований и спортивных интервал-актов на Константинопольском ипподроме (Schrodt, 1981, p. 51-52) (рис. 1-2); фрески и мозаики с изображением святых воинов и некоторых императоров (они дают информацию об оружии и доспехах ${ }^{2}$ ) (рис. 3-4); книжные миниатюры с изображением боевых сцен (Ioannes Scylitzes, Manuscrito) (рис. 5); apxeологические находки, в том числе из Херсонеса Таврического (византийского Херсона), где обнаружены не только остатки оружия, боеприпасов и военного снаряжения, но и две уникальные костяные пластины X века с изображением вооруженных юных стратио-

\footnotetext{
Авторы выражают признательность А.А. Роменскому за помощь в работе с греческими текстами.

Несмотря на то, что изображаемые на иконах святые воины, как правило, жили в поздней античности, византийские авторы отображали их хотя и архаизировано, но как правило в современных (для времени создания изображения) доспехах и с актуальным оружием, пусть и стилизованным.
} 
тов (рис. 6) (Наследие византийского Херсона, 2011, с. 287, рис. 317-318).

Особенностью византийского подхода к доармейской подготовке был отказ от античной системы спортивных школ - палестр и гимнасиев, организация деятельности которых у греков и римлян составляла одну из важных функций муниципального самоуправления, а их содержание - одну из крупных статей расходов городского бюджета или магистратов (Курбатов, 1962, с. 242). Произошло это, вероятно, под давлением Церкви, т.к. античный спорт был тесно связан с языческими культами. В Константинополе последняя палестра закрылась во времена Юстиниана I. По информации Прокопия Кесарийского, владелец палестры, гимнаст по имени Андрей, закрыл ее и служил офицером в императорской армии (Giatsis, 2007, p. 23). Гимнасии подвергались сносу, а добытый при этом камень использовался для возведения других сооружений, например, оборонительных стен в Фессалонике (Giatsis, 2007, p. 24).

Поэтому физическая подготовка юношества стала с VI века задачей семьи, не важно - знатной или простой. Занимались этим отцы или другие родственники ромеев. Именно так обучался искусству верховой езды, управления колесницей и охоты сын императора Маврикия (582-602): его тренировками руководил родной дед, отец матери принца (Феофилакт Симокатта, 1957, с. 183). Спортивной и боевой подготовкой юного Дигениса Акрита, героя военного эпоса X-XII вв., руководил его отец. Активная фаза физического воспитания воина, согласно этому источнику, длилась с 12 до 14 лет (Дигенис Акрит, 1960, c. 43, 62). К 14 годам юноша достигал призывного возраста (рис. 6) и мог вступать в брак (Ariantzi, 2009, s. 54-55).

Мотивацией к занятиям спортом оставались спортивные соревнования, в которых участвовали и дети, и подростки, и юноши. С римских времен сохранялся обычай, по которому ромеи по воскресеньям собирались для отдыха за городом или деревней, где юноши соревновались в легкой атлетике (беге, прыжках, метании копья и диска, фехтовании на тренировочных мечах, плавании и гимнастике (Giatsis, 2007, p. 24, 33-35). Большие спортивные праздники устраивали в дни ярмарок и религиозных торжеств: об этом есть сведения и в раннесредневековых источниках, и в трудах автора конца XII в. патриарха Антиохийского (1193-1199) Феодора Вальсамона

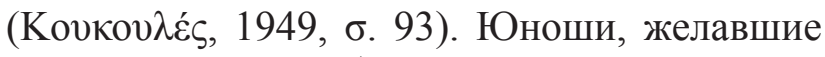
соревноваться публично, проверялись на физическое соответствие. К играм не допу-

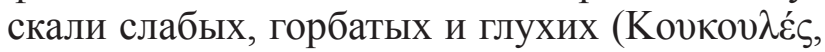
1949, б. 117).

Соревнования проводились в полдень, что делало и участие в них, и тем более победу, особенно трудными в условиях жаркого климата. Так было и во времена Иоанна Златоуста (ок. 350-407), упомянувшего об этой традиции (Коvкоvлє́s, 1949, б. 93), и позднее. Император Лев VI (886-912) советовал проводить тренировки стратиотов в самое жаркое время (Тактика Льва, 2012, с. 146), а его внук император Роман II в полуденный зной любил играть в конное поло (циканион) (Продолжатель Феофана, 1992, с. 195). Цель усложнения физической активности Лев VI объяснил в «Тактике»: «Такое обучение и такая тренировка не только приучают войско к трудам, но и оздоравливают.... Тело от всего этого становится крепким, подготовленным к предстоящим трудам и тяготам, приученным к жаре и зною» (Тактика Льва, 2012, с. 147).

Поскольку спорт был нацелен в первую очередь на совершенствование боевых навыков, большое значение придавалось различным видам единоборств, страсть к которым была унаследована от античности: антиохийский ритор IV века Либаний (наставник Иоанна Златоуста) отмечал увлечение жителей своего города этим видом спорта (Либаний, 1916, c. 450).

Византийские вариации на тему борьбы и бокса имеют значительные отличия от того, какими мы их видим их сейчас. Условия для соревнующихся были намного более жестокими. Не существовало весовых категорий и разграничений по возрасту (по крайней мере, свидетельств этого не обнаружено), поэтому о равной борьбе не могло быть и речи. Хотя, по свидетельству Либания, зрителям неравные поединки не нравились: «... в гимнастических состязаниях, когда жребий заставляет выступить против лучшего борца того, кто намного ему уступает, победа достается лучшему, но рукоплесканий зрителей за венком не следует» (Либаний, 2014, с. 417).

В схватках не было фиксированного количества раундов или ограничений по времени. Бой шел до полного изнеможения одного из соперников (условного нокаута), а в борьбе - до трех бросков противника. Очень мало было запрещенных приемов. Не разрешалось лишь кусать оппонента и давить пальцами на 
глаза. А вот ломать противнику пальцы и бить лежачего было можно (Carr, 2010, p. 7).

Отдельной разновидностью борьбы был панкратион (греч. «все силы»), культивировавшийся и после запрещения языческих олимпиад. Многое из того, что не допускалось в борьбе, в панкратионе было разрешено. Борьба здесь дополнялась боевыми элементами: ударами ногами, ладонью и кулаком, а также целым рядом захватов и даже укусов оппонента (хотя последнее считалось признаком непрофессионализма). В этом виде спорта также не было весовых и временных ограничений, а страсти кипели настолько, что бой мог закончиться выдавленными глазами и даже смертельным исходом (Коvкоv $\varepsilon_{\varepsilon}$, , 1949, б. 105). Судьям порой было сложно контролировать ход боя и соблюдение правил. Поэтому они использовали палицы и хлысты, чтобы при необходимости останавливать схватку (Carr, 2010, p. 8).

Особенно опасным был кулачный бой, также сохранившийся с олимпийских времен. О нем неоднократно упоминают авторы разного времени: Макарий Египетский, Григорий Богослов и Иоанн Златоуст в IV в., Иоанн Малала в VII в., патриарх Фотий в IX в. (Коvкоv $\lambda \dot{\varepsilon} \varsigma, 1949$, б. 101). Как заметил Иоанн Златоуст, «кто ведет кулачный бой, боится будущего» (цит. по: Коvкоvлє́є, 1949, б. 104). Источники свидетельствуют о получении бойцами тяжелых травм, опасных кровопотерях, потере сознания, переломах черепа и даже отрывании противнику головы

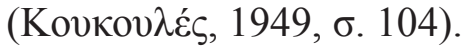

Эти случаи были нередки, а потому, требовали правового регулирования, что нашло отражение в «Василиках» - законодательстве периода правления Василия I (866-886) и Льва VI (Basilicorum 60.3.7). По закону, соревнования могли быть официальными, т.е. инициированными императорской или местной властью, а могли быть частными. В первом случае наказание за смерть соперника было мягче или отсутствовало вовсе, поскольку «ущерб произошел ради славы и мужества, а не ради несправедливости» (цит. по: Коvкоv $\lambda \dot{\varepsilon} \varsigma, 1949$, б. 123). В случае частного соревнования применялся трансформированный Дигестами Юстиниана древнеримский закон Аквилия об ответственности за убийство или членовредительство, т.е. виновника наказывали без скидок на спортивный азарт (Коvкои $\lambda \dot{\varsigma}$, , 1949, б. 124).
Участвовать в соревнованиях будущие воины начинали с детства. Одним из таких состязаний была стрельба из лука. Поразить мишень с наибольшей меткостью и стать победителем в этом виде спорта было честью для любого ромея (рис. 4) (Guttmann, 1981, p. 16-17), в том числе и для ребенка (Коvкоvде́s, 1949, б. 93). Хотя, как свидетельствует трактат Льва VI «Тактика», не умеющие стрелять из лука все же встречались (Тактика Льва, 2012, с. 136).

Будущие борцы, кулачные бойцы, мастера панкратиона, а значит, сильные и мужественные воины, с детства приучали себя к травмам и боли. На это были нацелены популярные у византийских мальчишек жестокие игры. Одной из них была забава под названием «петрополемос», проводившаяся за городскими стенами - у крепостного рва. Две команды становились по разные его стороны, набирали побольше камней, и руками, либо, что ещё более рискованно, с помощью пращи, закидывали команду соперника. Победу одерживала та команда, участники которой оставались на ногах, когда противник уже не мог сражаться. По окончании сражения победители устраивали себе «триумф», торжественно шествуя через городские ворота. Запрещена эта опасная игра была лишь в 1369 году и только на Крите. За несоблюдение запрета там предусматривался штраф (To chronikon tou Moreos, 5394-5). Правда, при оценке жестокости «потешного сражения» необходимо учитывать ширину рва. Согласно трактату X века «Как выдерживать осаду», она составляла не менее 50 локтей $(22,5$ м) (Анонимный воинский..., 2016, с. 512), что снижало опасность травмирования участников, особенно если броски совершались руками (рис. 6.2). А вот летящий примерно на 90 м. камень, выпущенный из пращи, несомненно, был очень опасен. Поэтому, не исключено, что в качестве пуль использовались менее травмирующие комочки подсушенной глины.

Более гуманно выглядит похожая на «казаки-разбойники» игра «ампра». Две команды, каждая из которых имела своего вождя и окруженное рвом место для содержания «пленных», поочередно преследовали друг друга, касанием руки захватывая в «плен» игроков соперника. Когда все участники одной из команд оказывались плененными, другая команда объявлялась победителем

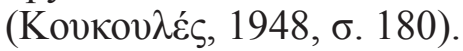


Из подготовленных в индивидуальных тренировках, закаленных в суровых играх и состязаниях юношей полководец отбирал в войско ополченцев-стратиотов. О критериях отбора пишут и Лев VI в «Тактике», и Никифор Фока в «Стратегике». Говоря о правилах подбора воинов, Лев VI, обращаясь к стратигу, пишет: «Выбирай из всего населения подвластной тебе фемы стратиотов не малолетних, но и не стариков, мужественных, сильных, здоровых, смелых, проворных» (Тактика Льва, 2012, с. 113). Никифор Фока формулирует свои требования точнее: «Подобающим и, в самом деле, нужным является избрание стратиотами из ромеев и армениев мужейоплитов, имеющих большой рост и возраст не более сорока лет» (Стратегика, 2005, с. 5).

В рамках военной подготовки на полевых лагерных сборах, в ходе мобилизации и в походе тренировки и соревнования приобретали ярко выраженный военно-прикладной характер. Описывая упражнения в боевых построениях, Маврикий критикует командиров, полагающих, что утомительные и долгие тренировки не имеют смысла и чрезмерны для войска, приводя в пример профессиональных спортсменов: «Возможно, некоторые из наиболее нерешительных и осторожных людей сочтут, что такое построение слишком сложно и многообразно, а потому, требует много усилий. Но им следовало бы знать, что борцы, возничие и другие им подобные, состязающиеся ради одного удовольствия, для которых успех измеряется денежной выгодой и ее величиной, а неудача - печалью, не сопряженной с ущербом, обременяют себя такими тяжелыми трудами и страданиями, включая воздержание в пище, и такой неустанной тренировкой, чтобы научиться приносить неудачу соперникам, защитить себя от вреда, причиняемого ими, и таким образом уметь разрушить козни, заранее к ним подготовившись» (рис. 1-2) (Стратегикон, 2004, с. 121).

В первую очередь это касается отработки навыков стрельбы из лука (рис. 3): на дальность, меткость и скорость. Согласно «Стратегикону», упражняться надлежало: «в пешем строю - в скоростной стрельбе из лука и ромейским, и персидским ${ }^{3}$ способами, то есть

Ромейский способ натягивания тетивы большим и указательными пальцами (щипковый хват, предпочтителен, когда стрелять нужно сильно); персидский способ - тремя средними пальцами (средиземноморский хват, предпочтителен, когда стрелять нужно метко) (Стратегикон, 2004, с. 64, 184, Люттвак, 2010, с. 383). в навыке быстро вынимать стрелу и сильно натягивать тетиву; то же самое полезно уметь и всадникам. В скоростной стрельбе из лука в пешем строю на определенное расстояние либо по копью, либо по другой цели. В скоростной стрельбе из лука на скаку верхом на коне в движении - вперед, назад, вправо, влево. Во вскакивании на коня. Имея натянутый лук в налучии, владеть копьем; быстро забросив его за спину, выхватить лук» (Стратегикон, 2004, с. 64). Как видим, владение луком не было преференцией подразделений лучников - псилов. Это было необходимым навыком, как для пехотинцев, так и для всадников, которые не должны были при этом забывать о своем основном оружии - менавлии (колющем копье) (рис. 4-5) 4 .

Войсковые подразделения лучников должны были также овладеть дополнительными навыками. Их тренировали в «скоростной стрельбе со щитом, метанию на расстояние и стрельбе из пращей; прыжкам и бегу» (Стратегикон, 2004, с. 204), - то есть всему тому, что изначально отрабатывалось в ходе детских «забав» и юношеских состязаний. Хороший псил должен был уметь не только быстро стрелять, в том числе из пращи (этому учил петрополемос), но и быстро двигаться (этому учила ампра).

Для эффективного владения византийским составным луком с обратным изгибом (Л.ттвак, 2010, с. 64), необходимо было иметь очень мощную мускулатуру рук, груди и спины, которую отлично развивали популярные у ромеев единоборства.

Маврикий сделал акцент на том, что «медленная стрельба бесполезна, даже если окажется, что стрела выпущена точно в цель» (Стратегикон, 2004, с. 64), акцентируя внимание на выработке навыка скоростной стрельбы. Наиболее эффективным способом таких тренировок считались упражнения в стрельбе во время перехода на театр боевых действий, как неотъемлемая его часть, что превращало марш в боевые учения: «Было бы хорошо, если все это стратиоты упражнялись проделывать верхом на конях во время марша в собственной земле: ведь при этом и переход завершится беспрепятственно, и кони не утомятся» (Стратегикон, 2004, с. 64).

Колющее копье (менавлия) достигало в длину 3,6 м., а его лезвие - 50 см. Их древка изготавливались из цельных сволов кизила или молодого дуба. Такие копья применялись против тяжелой кавалерии противника и, соответственно, сами были очень тяжелыми (Oxford Dictionary of Byzantium, 1991, p. 2192). 
Наиболее подробную информацию о приемах отработки меткой, сильной и быстрой стрельбы из лука содержит трактат VI в. «O стратегии»: «При стрельбе из лука мы стремимся к троякому результату: стрелять точно, стрелять сильно, стрелять быстро» (О стратегии, 2007, с. 145). Упражнения для решения этих задач автор описывает в трех главах своего наставления. Столь подробного описания тренировки лучников не содержит больше ни один византийский воинский трактат, хотя наставления, изложенные в «Стратегии», вероятно, не утратили своего значения и в дальнейшем, т.к. в «Стратегиконе» (Стратегикон, 2004, с. 64) и «Тактике» Льва VI (Тактика Льва, 2012, с. 145) они кратко упоминаются. В сочинении «О стратегии» большое внимание уделено соревновательному аспекту в отработке важнейшего воинского навыка тех времен, и методике тренировочного процесса.

При отработке меткости стрельбы важна поэтапность, чтобы неумелый стрелок не отчаялся, не попадая по сложным мишеням: «Знаки, по которым стреляют упражняющиеся, должны быть для начинающих широкими и высокими, иначе стреляющие, совершая промахи, могут впасть в уныние. Затем, уменьшая понемногу ширину, следует свести ее до узкой: ведь если стреляющие сначала будут промахиваться по обе стороны от знака, то после первой тренировки они, во всяком случае, не должны промахиваться по высоте. В конечном счете, должна быть понемногу сокращена и высота, так чтобы можно было использовать округленные мишени» (О стратегии, 2007, с. 146).

Когда воин приобретал навыки прицельной стрельбы, начиналась отработка выстрелов по движущимся мишеням. Цели следовало выбирать сложные - юрких и быстрых зверьков и птиц. Если же цели рукотворные, они должны быть мелкими и быстро приводиться в движение. В этом случае стрелять следовало «по тем целям, которые можно тянуть с помощью веревок на определенной дистанции, например, по шарам или чемулибо подобному. Очевидно, что каждый, кто прошел такую тренировку, сможет продемонстрировать точность стрельбы и в реальных боевых условиях» (О стратегии, 2007, с. 146).

Силу стрельбы отрабатывали в ходе соревнований с использованием механизма, фиксирующего кинетическую энергию удара стрелы при попадании в цель. На горизонтальное основание вертикально крепился брусок. К его верхнему концу горизонтально неподвижно крепился диск с 360 делениями на расстоянии 1о одно от другого по внешней окружности диска. В центре диска на железном стержне закреплялся деревянный круг в три пальца толщиной (ок. 6 см) диаметром в 2 пяди (ок. 35 см) в качестве туго поворачивающейся мишени (рис. 7). Стрельба велась стрелами с затупленными металлическими наконечниками. Количество делений горизонтального диска, на которые отклонился вертикальный круг, фиксировало силу выстрела (O стратегии, 2007, с. 147), что позволяло участникам состязания набирать и суммировать очки, определявшие победителя и призеров. Соревнования в силе стрельбы можно было проводить в разных номинациях: стоя, с колена, в движении (шагом или бегом), верхом (статично или на скаку). Мотивацией к улучшению результатов, таким образом, становился спортивный азарт.

Соревновательное начало задействовалось и при отработке скорости стрельбы: здесь применялся метод «гонки за лидером». Выстрелы производились всеми участниками по одной общей мишени стрелами с острыми наконечниками, на время: от стартового до финишного сигналов. Вначале в течение отведенного времени стрельбу вел опытный боец, искусный в скорострельности. Его результат (количество стрел в мишени) считался ориентиром для участников соревнования. Очистив мишень от стрел чемпиона, по сигналу, за отведенное время по ней стреляли соревнующиеся. Стрелы каждого из них были помечены знаками, позволяющими идентифицировать владельца. Тот, у кого в мишени оказывалось больше стрел, объявлялся победителем (O стратегии, 2007, с. 148).

Можно лишь догадываться, были ли в этой дисциплине отборочные соревнования в составе мелких подразделений, а затем - финалы на уровне банды, тагмы или даже фемы. Таких сведений источники, к сожалению, не содержат. Но многократные упоминания соревнований по стрельбе из лука, от Константинопольского ипподрома (Guttmann, 1981, p. 20)

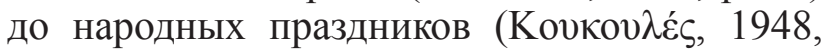
б. 93), позволяют предположить, что состязались и на меткость, и на силу, и на прицельную дальность, и на скорость.

Для тренировки стрельбы в движении на лошадях использовался похожий метод: «Пусть тот, кто искусен в скоростной стрельбе, возьмет лук и стрелы и, двигаясь вперед по 
прямой линии, посылает стрелы вбок от себя в течение определенного времени. После того, как он остановится, стрелы следует собрать, отметив места падения каждой из них. Место остановки будет обозначать первый рубеж. Отступив назад на расстояние примерно тридцати оргий (60 метров - авт.), следует отметить еще один рубеж, который называется вторым. Упражняющиеся должны быстро двигаться вслед друг за другом в направлении от этого второго рубежа к первому, отправляя стрелы до тех пор, пока не будет достигнута конечная отметка» (О стратегии, 2007, с. 148). $\mathrm{B}$ качестве плеймейкера также задействовали опытного стрелка, результат которого служил ориентиром для остальных. Соревнующиеся ехали не по одному, а друг за другом, то есть им следовало учитывать при стрельбе расстояние между лошадьми, что дополнительно усложняло задачу. Такого рода тренировкам подвергалось, видимо, большинство воинов, что говорит о высокой планке требований к владению стрельбой из лука.

В качестве практических учений по отработке полученных таким образом навыков использовалась охота. И в ранне-, и в средневизантийский периоды ее ценили как метод массовой тренировки воинов, но только как плановое мероприятие, а не спонтанную забаву. Автор «Стратегикона» наставлял: «Если по пути движения встретятся или попадутся дикие животные, их преследование должно быть запрещено, так как при этом поднимаются суматоха и крик, а лошади утомляются без необходимости» (Стратегикон, 2004, с. 83). Но, как замечает Лев VI, «поскольку занятия охотой приносят не только много душевных волнений стратиотам и тренировку лошадям, но и опыт боевых построений, необходимо тренировать стратиотов путем постоянных занятий охотой в подходящие и благоприятные периоды времени, когда неопытные получают возможность легко обучиться, а те, кто, возможно, совершит промах, - исправить свои ошибки, не претерпев наказания» (Тактика Льва, 2012, с. 229). Армейскую охоту следовало тщательно организовать: зверя выслеживали накануне. Акцент делался на построение в боевой порядок и окружение зверя и либо расстрел его из луков, либо, при наличии времени, более плотное окружение и поражение в ближнем бою. Так охота превращалась в полноценные военные учения.

Большая часть византийской армии раннего и фемного периодов состояла из тяжело вооруженных пехотинцев - скутатов. Согласно наставлениям Льва VI, полученные ими в детстве и отрочестве навыки в занятиях петрополемосом и единоборствами в армейской среде развивали в военно-прикладном направлении. Они сходились в единоборствах на палках с использованием щитов, метали дротики на дальность (Тактика Льва, 2012, с. 146).

Отработав индивидуальные боевые навыки, переходили к их совершенствованию в ходе тренировочных сражений, также проводившихся в форме соревнования. Лев VI наставлял стратига: «Разделив войско на части, заставь вести сражение друг с другом холостым оружием, то есть копьями и стрелами без наконечников, либо ... деревянными или тростниковыми палками вместо мечей, либо копьями, сделанными из тростника... Если местность, на которой происходит тренировка, каменистая, прикажи метать камни друг в друга в ходе тренировочной стычки» (Тактика Льва, 2012, с. 146). Последнее из приведенных указаний - прямое свидетельство использования петрополемоса в войсковой подготовке. Еще одно противоборство предназначалось для выработки навыков боевых действий в горной местности из невыгодного пространственного положения: «Показав крутые холмы, прикажи бегом подниматься на них и спускаться, и когда одни из стратиотов поднимутся на эти холмы, прикажи другим напасть на них» (Тактика Льва, 2012, с. 146). Военные учения, как и спортивные соревнования, проводились в максимально некомфортное для этого время суток: «хорошо проводить тренировки в знойное время и приучать стратиотов к нему» (Тактика Льва, 2012 , c. 153).

Таким образом, массовая физическая подготовка византийских мальчиков, подростков и юношей призывного возраста, несмотря на ликвидацию палестр и гимнасиев, представляла собой хорошо продуманную и логично выстроенную систему, нацеленную на воспитание сильного, смелого и закаленного воина, не боящегося ни жары, ни холода, ни боли, ни усталости. Лев VI подчеркивал, что именно тяжелые тренировки делают из новобранца приученного к тяготам воина: «Такое обучение и такая тренировка не только приучают войско к трудам, но и оздоравливают» (Тактика Льва, 2012, с. 147).

Наличие системы массовой физической подготовки юношества было чрезвычайно 
важным для огромной империи, которая всю ее историю была вынуждена вести тяжелые войны на выживание. Как показывает сопоставление различных видов источников, такая система в империи была. Ее принципиальное отличие от античных принципов физического воспитания заключалось в том, что физическое воспитание детей и подростков было возложено не на государство или общину, а на семью. Задачей общины при этом было создание условий для проведения спортивных соревнований, в ходе которых выявлялись чемпионы, становившиеся кумирами для сверстников. Государство подключалось к физическому воспитанию юношей после их включения в воинские списки в ходе учений и боевых походов. Основными мотивами к физическому совершенствованию были: стремление к воинскому идеалу, который олицетворяли легендарные воины древности, а также Армурис и Дигенис Акрит; патриотизм, тщательно культивировавшийся особенно в средневизантийский период; и дух спортивного соперничества, который пронизывал всю сферу физической культуры - от детских забав до военных учений.

\section{ЛИТЕРАТУРА}

Анонимный воинский трактат «Как выдерживать осаду» / пер. и коммент. В.В. Хапаева // Хапаев В.В. Византийский Херсон на рубеже тысячелетий: вторая половина X - первая половина XI в. Симферополь: Нижняя Оріанда, 2016. С. 509-538.

Армурис // Памятники Византийской литературы IX-XV веков / Отв. ред. Л.А. Фрейберг. М.: Наука, 1968. C. $158-160$.

Дигенис Акрит. 1960. М.: Изд-во АН СССР. 1960. 218 с.

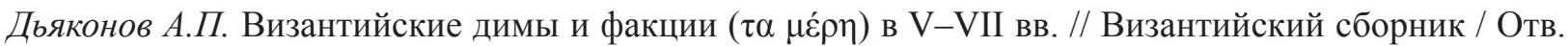
ред. Е. А. Косминский М., Л.: АН СССР, 1945. С. 144-227.

Курбатов Г.Л. Ранневизантийский город (Антиохия в IV веке). Л.: Изд-во ЛГУ, 1962. 284 с.

Лазарев В.Н. История византийской живописи. М.: Искусство, 1986. 194 с.

Левченко М.В. Венеты и прасины в Византии V-VII вв. // Византийский временник. 1947. Т. 1. С. 164-183.

Либаний. Речи. Том І. Казань.: Тип. имп. ун-та, 1914. 511 с.

Либаний. Речи. Том II. Казань.: Тип. имп. ун-та, 1916. 569 с.

Люттввак Э.Н. Стратегия Византийской империи. М.: Университет Дмитрия Пожарского, 2010. 664 c.

Михаил Пселл. Хронография / пер., статьи и коммент. Я. Н. Любарского М.: Наука, 1978. 319 с.

Никифор Григора. История ромеев. Т. І / пер. с греч. Р. В. Яшунского, вступ. ст. Л. Герд. СПб.: Свое издательство, 2013. $438 \mathrm{c.}$

О стратегии. Византийский военный трактат VI века / Изд. под-гот. В.В. Кучма. СПб.: Алетейя, 2007. $158 \mathrm{c}$.

Продолжатель Феофана. Жизнеописания византийских царей / пер., статьи и коммент. Я. Н. Любарского М.: Наука, 1992. 348 с.

Стратегика Никифора II Фоки / пер. и комм. А. К. Нефёдкина. СПб.: Алетейя, 2005. 105 с.

Стратегикон Маврикия / Изд. подгот. В.В. Кучма. СПб.: Алетейя, 2004. 242 с.

Тактика Льва / пер.: проф., д.ист.н. В.В. Кучма. СПб.: Алетейя, 2012. 367 с.

Титмар Мерзенбургский. Хроника. М.: Русская панорама, 2009. 256 с.

Успенский Ф.И. Партии цирка и димы в Константинополе // Византийский временник. 1894. Т. 1. C. $1-16$.

Феофилакт Симокатта. История. М.: Изд. АН СССР, 1957. 224 с.

Хапаев B.B. Физическое воспитание в Византийской империи IX-XII вв. // Традиции античного олимпизма в мировой культуре: от древности до наших дней / Под ред. Т. Б. Гвоздевой. М.: Изд-во Лит. ин-та имени А.М. Горького, 2015. С. 149-164.

Хомутский B. Византийское оружие и доспехи на изобразительных источниках. 2016. URL: https:// historicaldis.ru/blog/43826515054/Vizantiyskoe-oruzhie-i-dospehi-na-izobrazitelnyih-istochnikah?utm referrer=mirtesen.ru\&page $=2$ (Дата обращения 09.11.2020).

Чекалова A.A. К вопросу о димах в ранней Византии // Византийские очерки: труды советских ученых к XVI Междунар. конгрессу византинистов / Отв. ред. 3. В. Удальцова. М.: Наука, 1982. С. $37-53$. 
Яшаева Т., Денисова Е., Гинькут Н., Залеская В., Журавлев Д. Наследие византийского Херсона / Севастополь: Телескоп, Остин : ИКА Техас. ун-та, 2011. 708 с.

Ariantzi D. Aspekte der Kindheit in Byzanz vom 6. bis 11. Jahrhundert im Spiegel hagiographischer Quellen. Wien: Dissertation, 2009.350 s.

Carr T., Sheppard K., Welch A. Sport During the Byzantine Era. Byzantium as a Context for Social Sciences Research. 2010. P. 1-15.

Crowther N. Sports Violence in the Roman and Byzantine Empire: A Modern Legacy // International Journal of the History of Sport. 1996. No 3. P. 445-458.

Giatsis S.G. The organization of chariot racing in the great hippodrome of byzantine Constantinople // The International Journal of the History of Sport, 2000. 17:1. P. 36-68.

Giatsis S.G. Sport in Byzantium // Erytheia. 2007. No. 28. P. 15-40.

Guilland R. Études sur l'Hippodrome de Byzance III-IV // Byzantinoslavica. 1965. No. 26. P. 1-33.

Guttmann A. Sport Spectators From Antiquity To The Renaissance // Journal Of Sport History, 1981. Vol. 8, No. 2, P. 16-17.

Ioannes Scylitzes. Synopsis historiarum // Manuscrito del siglo XII / Biblioteca Nacional de España. 234 [i.e. 233].

Oxford Dictionary of Byzantium. Oxford: Oxford University Press, 1991. 2238 p.

Schmitt J. The chronicle of Morea (To chronikon tou Moreos): a history in political verse, relating to the establishment of feudalism in Greece by the Franks in the thirteenth century. London: Methuen, 1904. 778 p.

Schrodt B. Sports in the Byzantine Empire // Journal Of Sport History. 1981. Vol. 8. No. 3. P. 51-52.

Wolińska T. Constantinopolitan Charioteers and Their Supporters. Łódź: Studia Ceranea 1, 2011. P. 127-142.

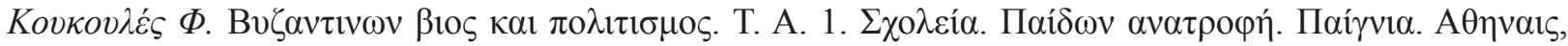
1948. $231 \sigma$.

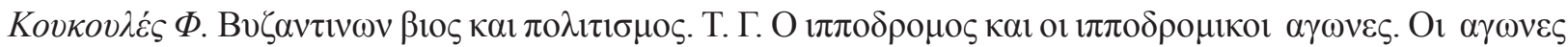

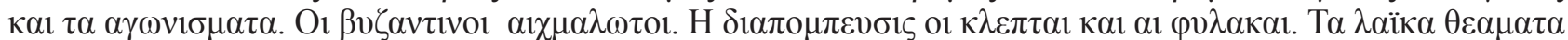

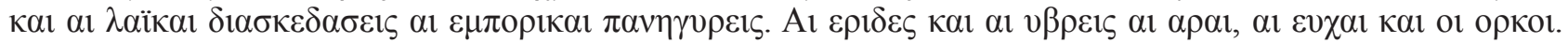

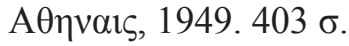

\section{Информация об авторах:}

Хапаев Вадим Вадимович, кандидат исторических наук, зам. директора Института общественных наук и международных отношений, доцент кафедры «История» Севастопольского государственного университета (г. Севастополь, Россия); khapaev007@mail.ru

Глушич Антон Михайлович, магистрант Национального исследовательского университета «Высшая школа экономики» (г. Москва, Россия); barny.g@mail.ru

\section{REFERENCES}

Anonimnyi voinskii trakat "Kak vyderzhat' osadu" (Anonymous Military Treatise "How to Withstand a Siege") In Khapaev, V. V. 2016. Vizantiiskii Kherson na rubezhe tysiacheletii: vtoraia polovina X - pervaia polovina XI v. (Byzantine Kherson at the Turn of the Millennia: Second Half of 10th - First Half of 11th cc.). Simferopol: "Nizhniaia Orianda" Publ., 509-538 (in Russian).

1968. Armuris (Armouris) In Freiberg, L. A. (ed.). Pamiatniki Vizantiiskoi literatury $I X-X V$ vekov (Monuments of Byzantine Literature of the 9th-15th Centuries). Moscow: "Nauka" Publ., 158-160 (in Russian). Digenis Akrit (Digenes Akritas). 1960. Moscow: Academy of Sciences of the USSR Publ. (in Russian).

D’yakonov, A. P. 1945. In Kosminskii, E. A. (ed.). Vizantiiski sbornik (Byzantine Collection). Moscow; Leningrad: Academy of Sciences of the USSR, 144-227 (in Russian).

Kubratov, G. L. 1962. Rannevizantiiskii gorod (Antiokhiia v IV veke) (Early Byzantine Town (Antioch in the 4th Century)). Leningrad: Leningrad State University (in Russian).

Lazarev, V. N. 1986. Istoriia vizantiiskoi zhivopisi (History of Byzantine Graphic Art). Moscow: "Iskusstvo" Publ. (in Russian).

Levchenko, M. V. 1947. In Vizantiyskiy Vremennik (Byzantine Yearbook) 1, 164-183 (in Russian).

Libanius. 1914. Rechi (Speeches) 1. Kazan: Typography of the Imperial University (in Russian).

Libanius. 1916. Rechi (Speeches) 2. Kazan: Typography of the Imperial University (in Russian).

Lyuttvak, E. N. 2010. Strategiia Vizantiiskoi imperii (The Grand Strategy of the Byzantine Empire). Moscow: University Of Dmitry Pozharsky (in Russian). 
Psell, M. 1978. Khronografiia (Chronography). Lyubarskii, Ya. N. (transl.). Moscow: "Nauka" Publ. (in Russian).

Nicephorus Gregoras. 2013. Istoriia romeev (History of the Romei) 1. Saint Petersburg: "Svoe izdatel'stvo" Publ. (in Russian).

Kuchma, V. V. (ed.). 2007. O strategii. Vizantijskii voennyi traktat VI veka (On Strategy. Byzantine Military Treatise of the 6th century). Saint Petersburg: "Aleteiia" Publ. (in Russian).

Theophanes Continuatus. 1992. Zhizneopisaniia vizantiiskikh tsarei (Biographies of Byzantine Kings). Moscow: "Nauka" Publ. (in Russian).

Nefyodkin, A. K. 2005. (ed.).Strategika Nikifona II Foki (Strategica by Nikephoros II Phokas). Saint Petersburg: "Aleteiia" Publ. (in Russian).

Kuchma, V. V. (ed.). 2004. Stratekikon Mavrikiia (Strategikon of Maurice). Saint Petersburg: "Aleteiia" Publ. (in Russian).

Kuchma, V. V. (ed.). 2012. Taktika L'va (Lion's Tactics). Saint Petersburg: “Aleteiia” Publ. (in Russian).

Titmar Merzenburgskii. 2009. Khronika (Chronicle). Moscow: "Russkaia panorama” Publ. (in Russian).

Uspenskii, F. I. 1894. In Vizantiyskiy Vremennik (Byzantine Yearbook) 1,. 1-16 (in Russian).

Feofilakt Simokatta, 1957. Istoriia (History). Moscow: Academy of Sciences of the USSR (in Russian).

Khapaev, V. V. 2015. In Gvozdeva, T. B. (ed.). Traditsii antichnogo olimpizma v mirovoi kul'ture: ot drevnosti do nashikh dnei (Traditions of Ancient Olympism in World Culture: from Antiquity to the Present Day). Moscow: Maxim Gorky Literature Institute Publ., 149-164 (in Russian).

Khomutskii, V. 2016. Vizantiiskoe oruzhie i dospekhi na izobrazitel'nykh istochnikakh (Byzantine Weapons and Armor in Graphic Sources) Available at: https://historicaldis.ru/blog/43826515054/Vizantiyskoe-oruzhiei-dospehi-na-izobrazitelnyih-istochnikah?utm_referrer=mirtesen.ru\&page=2 Accessed 09.11.2020)

Chekalova, A. A. 1982. In Udaltsova, Z. V. (ed.). Vizantiyskie ocherki (Bizantium essays). Moscow: "Nauka" Publ., 37-53.

Yasheva, T., Denisova, E., Ginkut, N., Zalesskaya, V., Zhuravlev, D. 2011. Nasledie vizantiiskogo Khersona (The Legacy of Byzantine Kherson). Sevastopol, Austin: “Telrskop" Publ., Texas University (in Russian).

Ariantzi, D. 2009. Aspekte der Kindheit in Byzanz vom 6. bis 11. Jahrhundert im Spiegel hagiographischer Quellen. Wien: Dissertation (in German).

Carr, T., Sheppard, K., Welch, A. 2010. Sport During the Byzantine Era. Byzantium as a Context for Social Sciences Research, 1-15.

Crowther, N. 1996. In International Journal of the History of Sport. 3, 445-458.

Giatsis, S. G. 2007. In Erytheia. 28, 15-40.

Giatsis, S. G. 2000. In International Journal of the History of Sport, 17:1, 36-68.

Guilland, R. 1965. In Byzantinoslavica. 26, 1-33 (in English).

Guttmann, A.1981. In Journal Of Sport History 8(2), 16-17 (in English).

Ioannes Scylitzes. Synopsis historiarum // Manuscrito del siglo XII / Biblioteca Nacional de España. 234 [i.e. 233].

1991. Oxford Dictionary of Byzantium. Oxford: Oxford University Press..

Schmitt, J. 1904. The chronicle of Morea (To chronikon tou Moreos): a history in political verse, relating to the establishment of feudalism in Greece by the Franks in the thirteenth century. London: Methuen.

Schrodt, B. 1981. In Journal Of Sport History. 8(3), 51-52 (in English).

Wolińska, T. 2011. Constantinopolitan Charioteers and Their Supporters. Łódź: Studia Ceranea 1, 127-142.

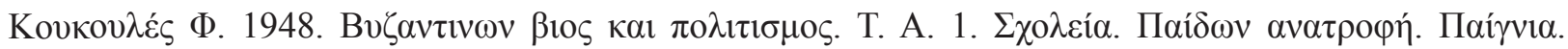

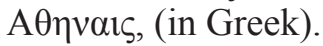

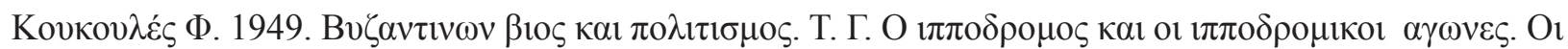

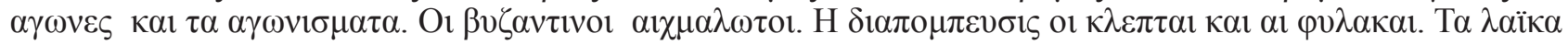

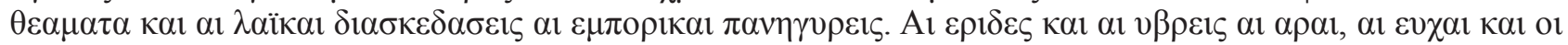

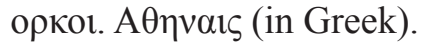

\section{About the Authors:}

Khapaev Vadim V., Candidate of Historical Sciences, Deputy Director at the Institute of Social Sciences and International Relations, Associate Professor at the History Department. Sevastopol State University. Universitetskaya Str., 33, Sevastopol, 299053, Russian Federation; khapaev007@mail.ru 
Glushich Anton M., Master student, National Research University Higher School of Economics. Myasnitskaya Str., 20, Moscow, 101000, Russian Federation; barny.g@mail.ru

Статья поступила в журнал 01.08.2020 г. Статья принята к публикации 01.09.2020 г. Авторы внесли равноценный вклад в работу.

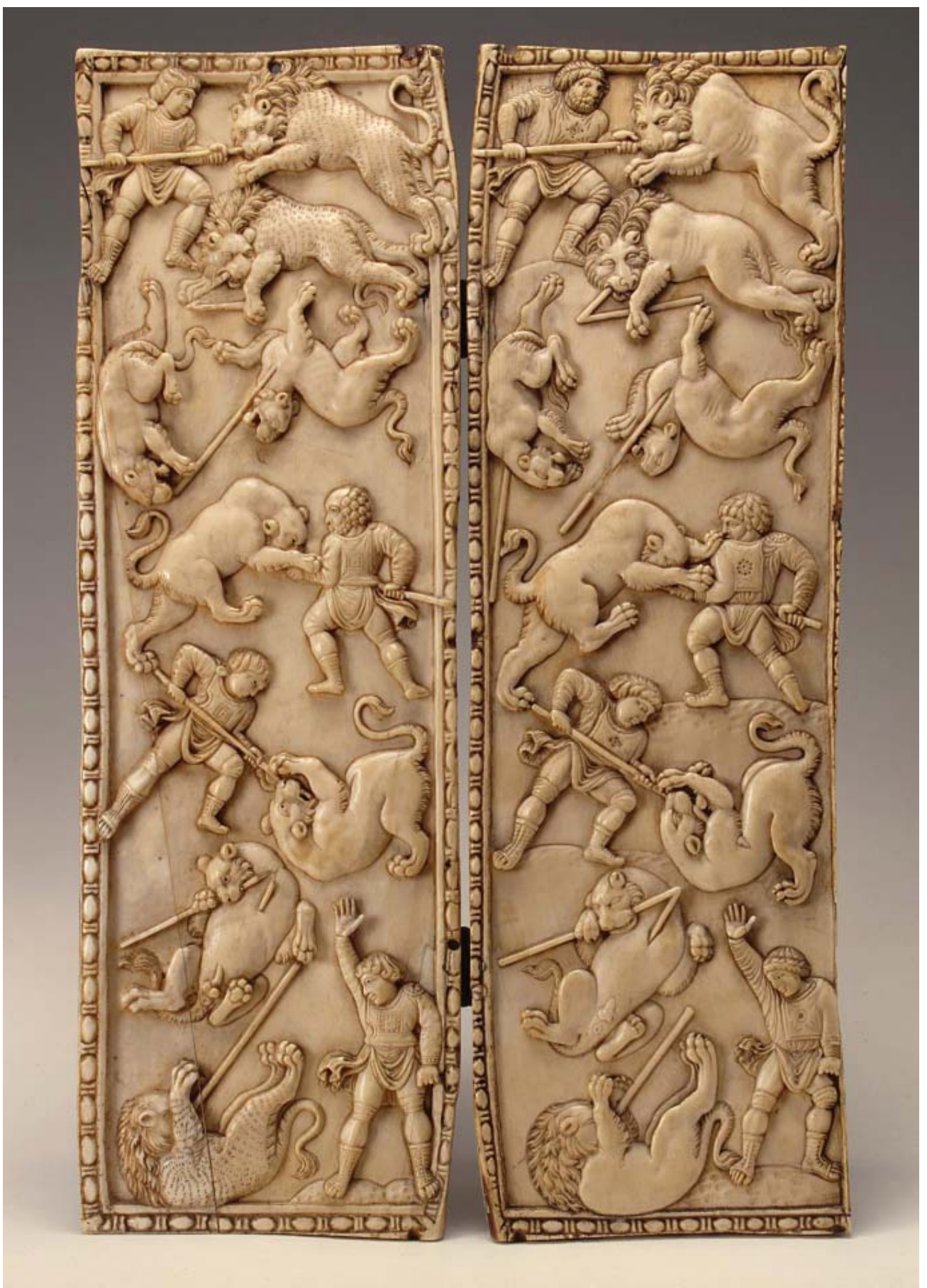

Рис. 1. Диптих с цирковыми сценами. ок. 500 г. Эрмитаж.Официальный сайт Государственного Эрмитажа. Режим доступа: https://www.hermitagemuseum.org

Fig. 1. Diptych with circus scenes. Circa 500. Hermitage. The official website of the State Hermitage. Available at: https://www.hermitagemuseum.org 


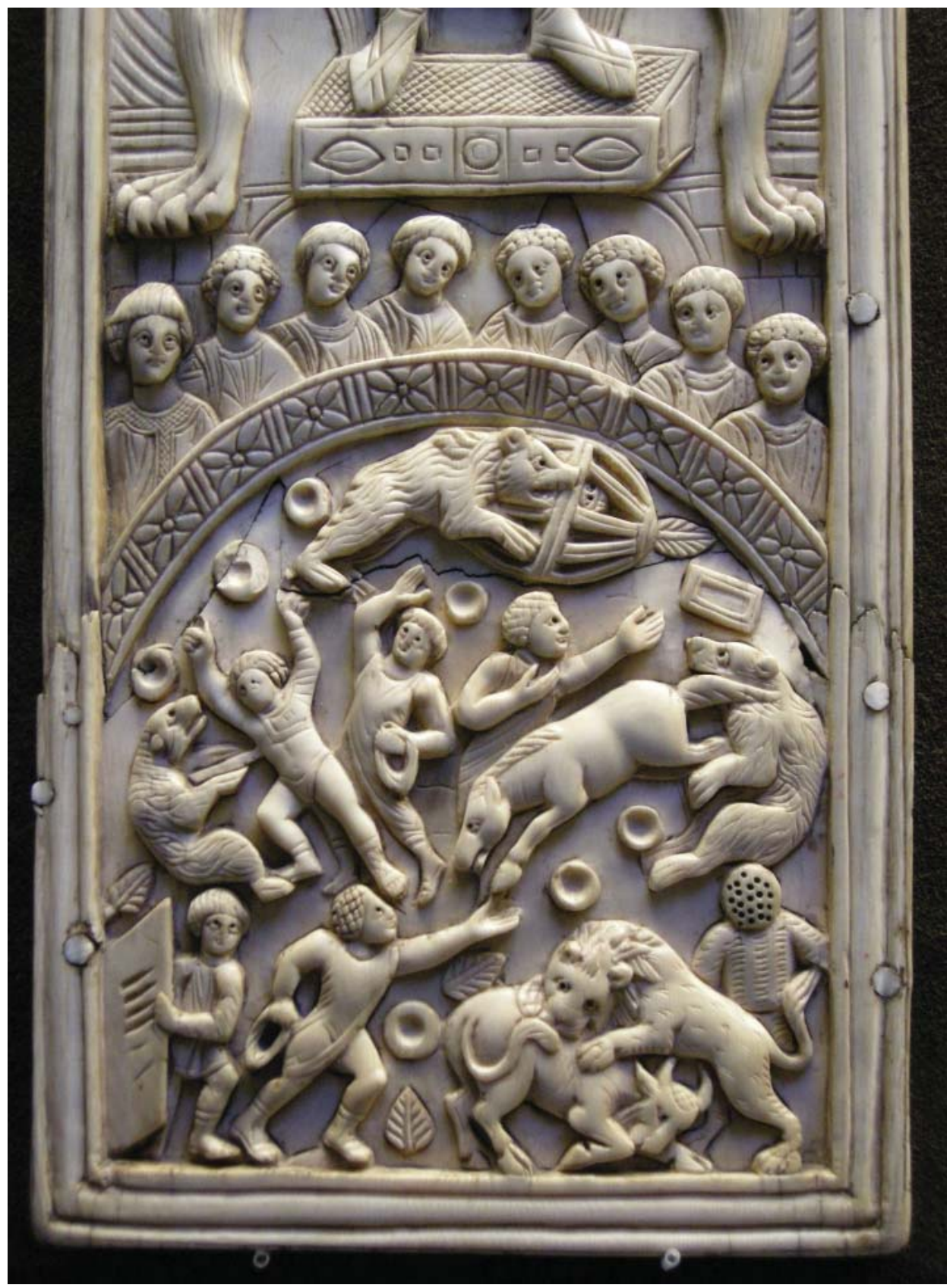

Рис. 2. Борьба людей со зверьми на константинопольском ипподроме. Диптих консула Ареобинда (фрагмент). 506 г. Эрмитаж. Официальный сайт Государственного Эрмитажа. Режим доступа: https://www.hermitagemuseum.org

Fig. 2. A fight between people and animals at the Constantinople hippodrome. Diptych of Areobindus Dagalaiphus (fragment). 506. Hermitage. Official website of the State Hermitage. Available at: https://www.hermitagemuseum.org 


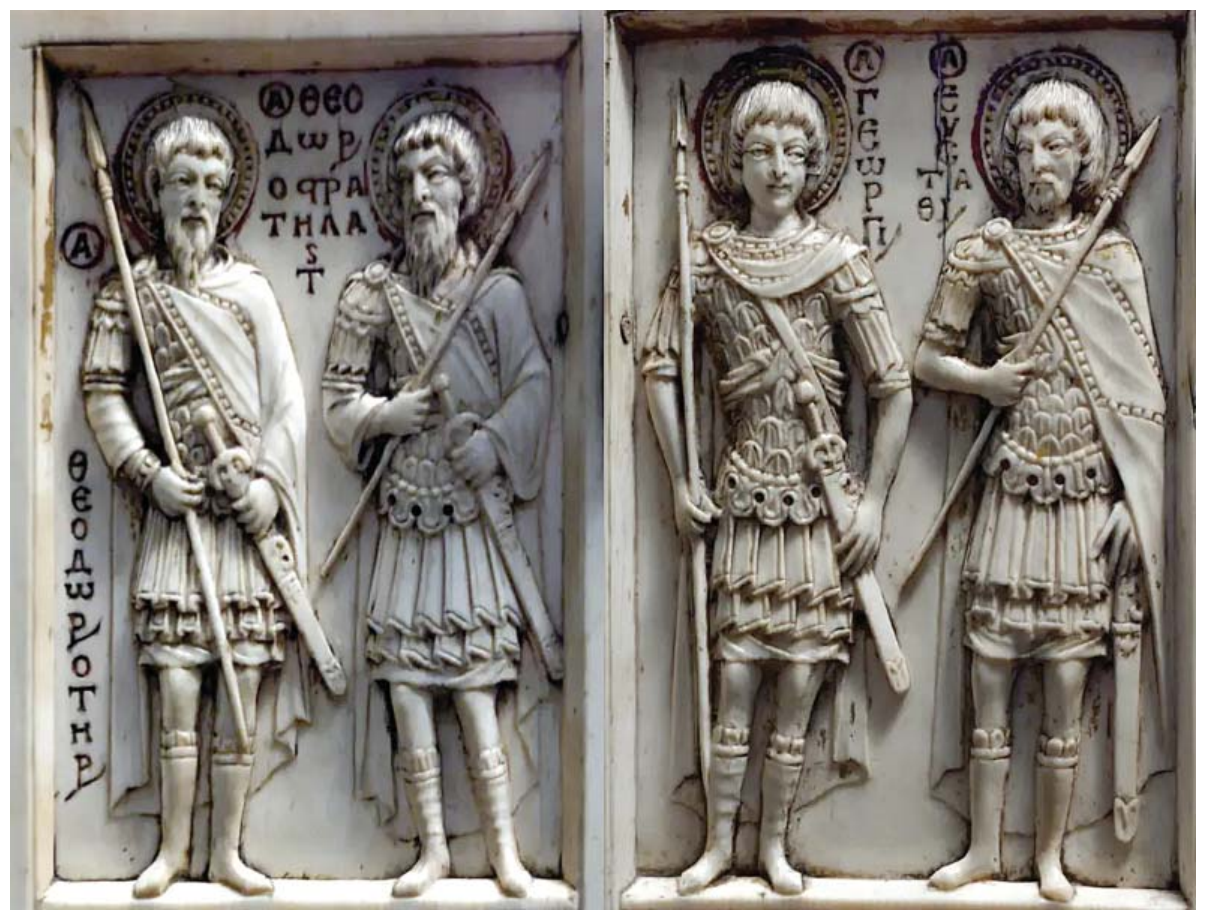

Рис. 3. Святые воины Феодор Тирон, Феодор Стратилат, Георгий Победоносец, Евстафий Великомученик. Фрагмент диптиха «Деисус со святыми». Сер. Х в.

(Хомутский, 2016)

Fig. 3. Warrior saints Theodore Tyron, Theodore Stratelates, Saint George, Saint Eustace the Great Martyr. Fragment of the diptych "The Deesis with the Saints". Mid- 10th century.

(Khomutsky, 2016)

Рис. 4. Святой Димитрий Солунский. Стеатитовая икона. Вооружен луком и колющим копьем (менавлием). ХІ в. Лувр (Хомутский, 2016)

Fig. 4. Saint Demetrius of Thessaloniki. Steatite icon. The person is armed with a bow and stabbing spear (menaulion). 11th century. The Louvre Museum (Khomutsky, 2016)

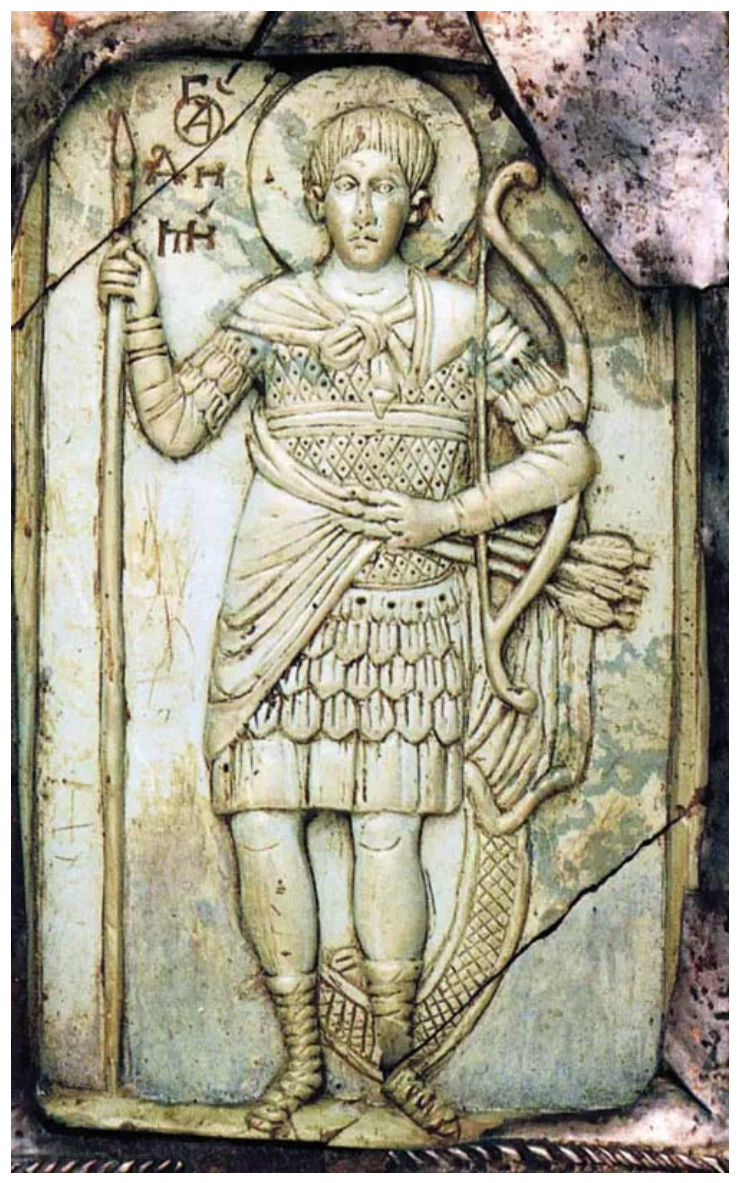




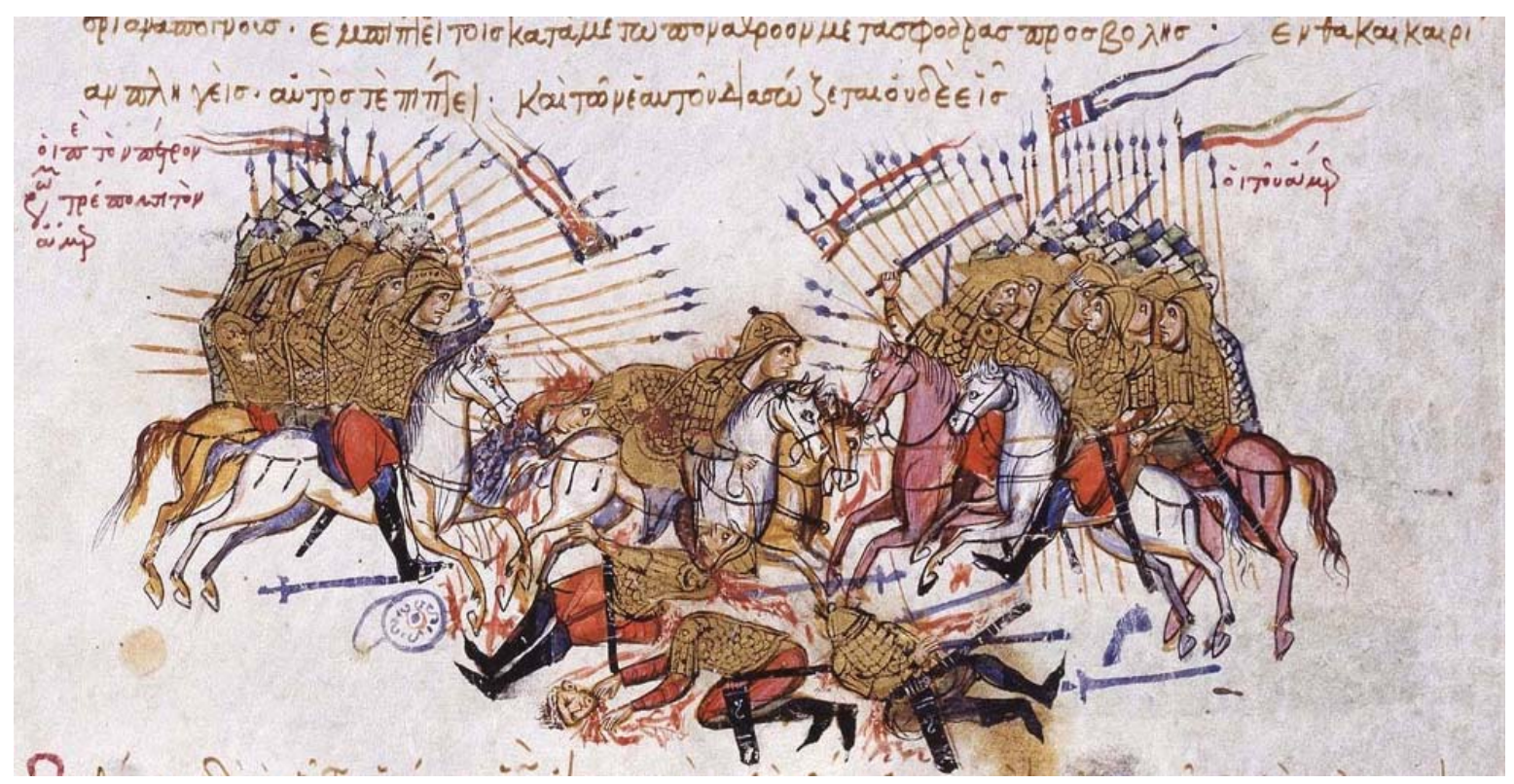

Рис. 5. Битва византийцев с арабами при Лалаконе 863 г. Миниатюра рукописи «Мадридский Скилица». XII в. Конные воины вооружены колющими копьями (менавлиями) и прямыми обоюдоострыми мечами (спатами) (Ioannes Scylitzes, Manuscrito, H. 155)

Fig. 5. The battle of the Byzantines with the Arabs at Lalakaon in 863. Miniature of the manuscript "Madrid Skylitzes". 12th century. Equestrian warriors armed with piercing spears (menaulions) and straight double-edged swords (spathae) (Ioannes Scylitzes, Manuscrito, H. 155)
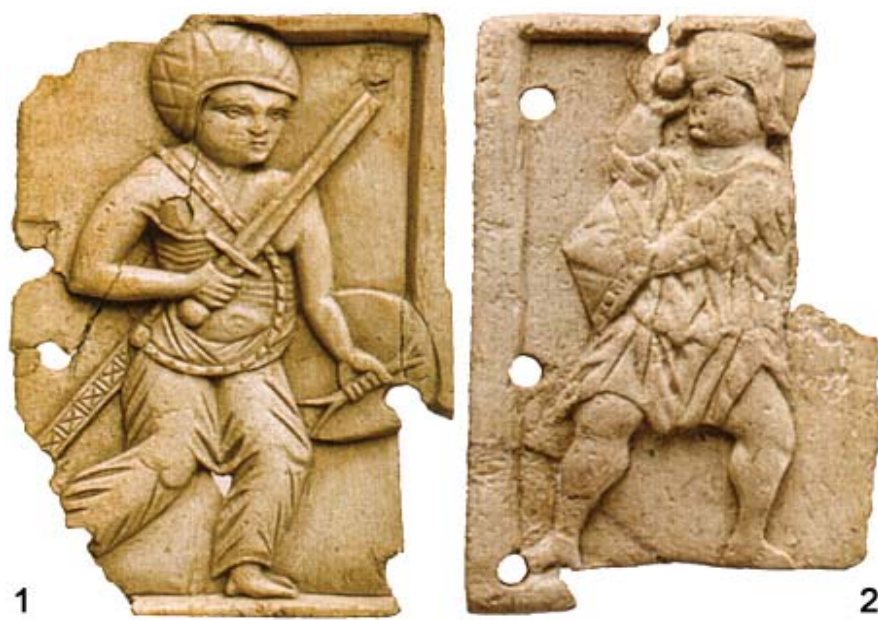

Рис. 6. Изображения воинов-подростков фемного ополчения (15-18 лет) на костяных пластинках из Херсонеса. Х век. Херсонесский государственный историко-археологический музей-заповедник

(Наследие византийского Херсона, 2011, с. 287, рис. 317-318).

Fig. 6. Images of adolescent warriors of the theme militia (15-18 years of age) on bone plates from Chersonesos. 10th c. Chersonesos State Historical and Archaeological Museum-Reserve (Heritage of Byzantine Kherson, 2011, p. 287, fig. 317-318).

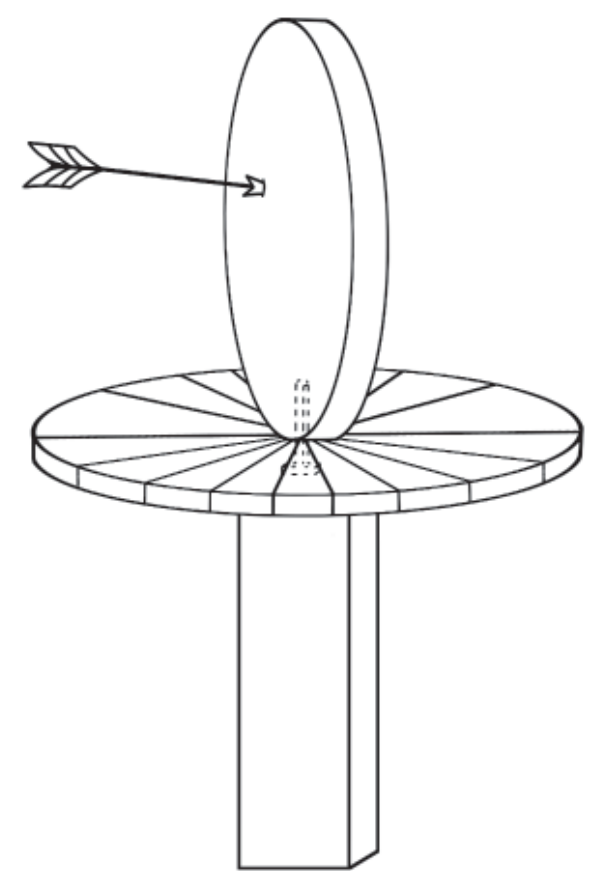

